\title{
Craniofacial chronological microdifferentiation of human prehistoric populations of the Azapa valley, northern Chile
}

\author{
Microdiferenciación cronológica craneofacial de poblaciones humanas prehistóricas \\ del Valle de Azapa, norte de Chile
}

FRANCISCO ROTHHAMMER ${ }^{1}$, CALOGERO M. SANTORO ${ }^{1} \&$ MAURICIO MORAGA ${ }^{2}$

\author{
${ }^{1}$ Universidad de Tarapacá, Facultad de Ciencias Sociales, Administrativas y Económicas, Departamento \\ de Arqueología y Museología, Casilla 6-D, Arica, Chile; \\ e-mail: frothham@machi.med.uchile.cl \\ ${ }^{2}$ Programa de Genética Humana, Instituto de Ciencias Biomédicas, Facultad de Medicina, Universidad \\ de Chile, Casilla 70061, Santiago 7, Chile
}

\begin{abstract}
Archeological evidence suggest that the cultural developments occurred in the highlands around lake Titicaca in the Central Andes, exerted influence on the cultural elaborations of the human groups that peopled the valley of Azapa, close to the city of Arica, and the Pacific coast of northern Chile. In this communication we show by means of a distance analysis, that a craniofacial differentiation accompanied the process of cultural evolution in the valley. The biological influence of Tiwanaku is partially reflected in craniofacial morphology, providing preliminary evidence that cultural changes were associated to intermittent gene flow from the highlands, specially during the Alto Ramírez and San Miguel phases.
\end{abstract}

Key words: craniometrical distance analysis, Andean prehistoric populations.

\section{RESUMEN}

Los desarrollos culturales ocurridos en el altiplano en el área circumtiticaca en los Andes centrales, ejercieron influencia sobre las elaboraciones culturales de los grupos humanos que poblaban el Valle de Azapa cercano a la ciudad de Arica y la costa del norte de Chile. En esta comunicación presentamos un análisis de distancias que demostró que una diferenciación craniofacial acompaño en el valle el proceso de evolución cultural. La influencia biológica de Tiwanaku se refleja parcialmente en la morfología craniofacial, proporcionando evidencia preliminar de que los cambios culturales en el valle se realizaron acompañados de flujo génico intermitente desde el altiplano, especialmente durante las fases Alto Ramírez y San Miguel.

Palabras clave: análisis de distancia craneométrica, poblaciones andinas prehistóricas.

\section{INTRODUCTION}

The first highland hunters that settled in northern Chile lived in rock shelters and open camps about 11,000 years ago (Santoro 1989, Rothhammer 1990, Grosjean \& Núñez 1994). Archaeological evidence indicates that post Pleistocene climatic conditions prevailed when these Archaic populations arrived, since no indication of the existence of megafauna in lower latitude camps was found. The first hunters supported their economy combining the capture of big (Camelidae), and small mammals (Ctenomidae, Chinchillidae), with the collection of some tubers and plants (Dauelsberg 1983, Santoro \& Núñez 1987). Their stone tools, made of basalt, quartz, obsidian, and chert, were manufactured according to characteristic patterns recognized along the Andes.
Between 7,000 and 6,000 years BP there was a dry interval in the highlands of Arica (Baied 1991), which may have affected the living conditions of hunters and gatherers (see Aldenderfer 1989). In this context it is interesting to note that a more intensive use of coastal camps started after 7,000 years BP, thus new technology was developed to cope with the exploitation of marine resources.

Although the question is not finally settled, there is evidence that these initial cultural elaborations may have been related to migrational events originating in the tropical forest (Rivera \& Rothhammer 1986, Rothhammer \& Silva 1988, 1992, Moraga et al. 2001, Rothhammer et al. 2001).

Around lake Titicaca, on the highlands, a cultural development occurred after 4,000 yearsBP 
that in the long run gave rise to the impressive Tiwanaku culture (ca. 1,600 years BP).

According to archeological information (Focacci \& Erices $1973^{1}$, Muñoz \& Focacci 1983) the cultural development around lake Titicaca exerted influence on the human groups that peopled the lower valley of Azapa and the Pacific coast. This process started after 1,600 years BP and continued probably until the arrival of the Spanish conquerors.

Recently, we presented an analysis of craniofacial measurements from skeletal remains exhumed in archeological cemeteries of the Azapa valley and the Arica littoral, with the object of reconstructing the biological history of the prehistoric inhabitants of the coast and the valley, in the context of their interaction with demographically and culturally more developed centers around lake Titicaca (Rothhammer \& Santoro 2001). On the basis of our results we suggested that during the Formative Period, gene flow occured from the highlands to the valleys, judging by a decrease in biological distance between samples representing both geographic areas. This suggestion was in disagreement with the conclusions of an earlier study of discrete dental traits (Sutter 1997). Our analysis included the computation of Mahalanobis $\mathrm{D}^{2}$ distance statistics (MDS) (Mahalanobis \& Majumdar 1949) among samples representing cemeteries. The relatively small size of some of the samples, unfortunately precluded the unbiased estimation of a correlation matrix between craniofacial distances and the cronological separation of the cemeteries.

In order to avoid this shortcoming we agglomerated in this study the samples of cemeteries belonging to similar cultural phases and computed MDS values among cultural phases. Furthermore, chronological separation of cultural phases (taking median times) occurring in the valley and the coast, characterized by material cultural artifacts such as pottery, basketry and tinctured tapestry among others, were subsequently correlated with the morphological microdifferentiation of the prehistoric populations studied, using craniofacial MDS as indicators.

\section{MATERIAL AND METHODS}

Adult osteological collections analyzed in this study where exhumed and measured according to

${ }^{1}$ FOCACCI G \& S ERICES (1973) Excavaciones en túmulos de San Miguel de Azapa. Actas del IV Congreso de Arqueología Chilena, Número especial, Universidad de Chile. standart procedures (Bass 1971) by archeologists from the Department of Archeology and Museology of the Universidad de Tarapaca, Arica. Samples from the following cemeteries located in the valley of Azapa and on the coast close to the city of Arica were studied. (Fig. 1): Morro1, AZ6, AZ-8, AZ-14, AZ-70, AZ-71, AZ-75, AZ-115, AZ-140, PLM-7 and PLM-4 (Focacci \& Erices 1973, Focacci 1974, Santoro 1980, Muñoz \& Focacci 1983, Allison et al. 1984). We have also included an adult cranial highland sample from lake Titicaca (Tiwanaku) (Posnansky 1914) for comparison.

Previous studies (Rothhammer \& Silva 1990) have shown that the following craniofacial measurements are particularly suitable for population comparisons involving prehistoric Amerindians: minimal frontal breadth, bizygomatic breadth, nasal height, orbital height, orbital breadth and palatal breadth. Sexes were pooled after removing sex differences by linear regression according to standard procedures.

In order to evaluate the influence of artificial cranial deformation, which was extensively practiced in pre-Columbian South America, on the craniofacial measurements used, univariate (t-tests) and multivariate MDS tests were applied after subdividing the crania into three groups: (1) anteroposterior deformed (AP), (2) circumferential deformed (C) and (3) normal (N) according to the criteria described by Anton (1989). MDS were estimated among crania agglomerated by cultural phases (Table 1). The statistical significance of MDS were tested, with reference to the F distribution with $\mathrm{p}$ and $\mathrm{k}$ degrees of freedom, being $\mathrm{p}$ the

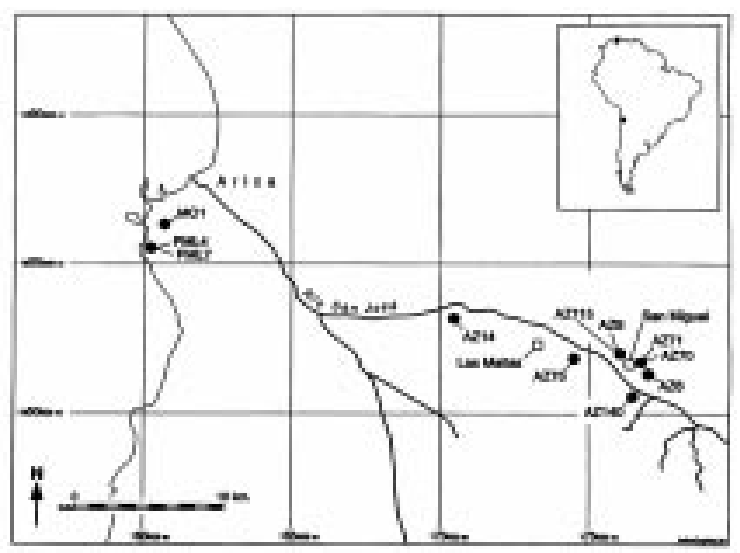

Fig. 1: Map of the Azapa valley with the location of cementeries included in the present study.

Mapa del Valle de Azapa con la ubicación de los cementerios incluidos en el presente estudio. 
TABLE 1

Cultural phases, with chronology and geographic location, present in the coastal valleys of Arica, Chile

Fases culturales con cronología y ubicación geográfica presentes en los valles costeros de Arica, Chile

\begin{tabular}{lcc}
\hline Cultural phases & $\begin{array}{c}\text { Chronology } \\
(\text { years BP) }\end{array}$ & Location \\
\hline Chinchorro & $8,000-4,000$ & Coast \\
Azapa & $3,500-2,500$ & Valley \\
Alto Ramírez & $2,500-1,700$ & Coast and valley \\
Maitas & $1,250-1,000$ & Valley \\
San Miguel & $1,000-700$ & Valley \\
Tiwanaku & $1,600-800$ & Highlands \\
\hline
\end{tabular}

number of variables and $\mathrm{k}=\mathrm{N}_{1}+\mathrm{N}_{2}-\mathrm{p}-1$ where $\mathrm{N}_{1}$ and $\mathrm{N}_{2}$ are the samples sizes of populations 1 and 2 respectively (Mahalanobis \& Majumdar 1949). The chronologic separation of cultural phases was measured taking median times.

\section{RESULTS}

The results of the univariate statistical treatment of differences among AP, $\mathrm{C}$ and $\mathrm{N}$ crania for six craniometric measurement indicate an absence of significant differences. MDS values between AP, $\mathrm{C}$ and $\mathrm{N}$ types for six measurements were also found to be insignificant. Craniometric means with standard deviations by cultural phase are shown in Table 2.

Turning now to the craniometric distance analysis, we note that the smallest distances were found between cronologically adjacent phases (Table $3)$. For example small distances were estimated between Azapa and Alto Ramírez, Alto Ramírez and Maitas, and Maitas and San Miguel. The distances between Chinchorro and the remaining phases are higher, as expected, since the chronological separation between these phases is also larger. It is noteworthy that the distances of Tiwanaku to the prehistoric populations of the Azapa valley decrease with time and are lowest during the Alto Ramírez and the San Miguel phases, providing preliminary evidence that intermittent gene flow from the highlands occurred

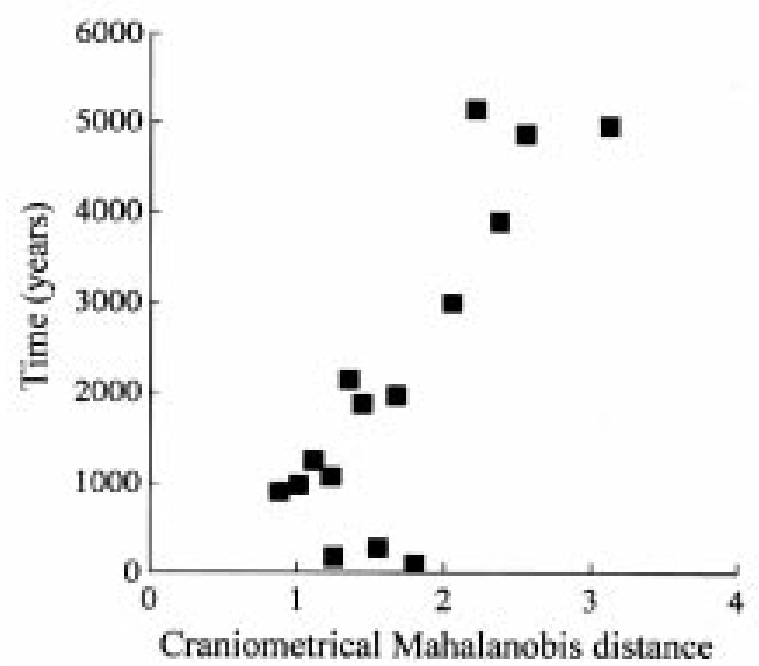

Fig. 2: Functional relationship between craniometrical Mahalanobis distance statistic (MDS) and time in the Azapa valley.

Relación funcional entre distancias craniométricas de Mahalanobis (MDS) y tiempo en el valle de Azapa.

TABLE 2

Means with standard deviations for six craniometric variables measured in prehistoric populations belonging to various cultural phases present in the coastal valleys of Arica, Chile and one highland sample

Promedios con desviaciones estándar para seis variables craneométricas medidas en poblaciones prehistóricas pertenecientes a varias fases culturales presentes en los valles de Arica, Chile y una muestra altiplánica

\begin{tabular}{|c|c|c|c|c|c|c|c|}
\hline Cultural phase & $\mathrm{n}$ & 1 & 2 & 3 & 4 & 5 & 6 \\
\hline Chinchorro & 102 & $92.7 \pm 4.4$ & $128.5 \pm 7.4$ & $48.8 \pm 2.8$ & $38.4 \pm 1.7$ & $34.9 \pm 2.0$ & $35.3 \pm 3.5$ \\
\hline $\begin{array}{l}\text { Azapa } \\
\text { Alto }\end{array}$ & 30 & $89.5 \pm 4.4$ & $133.3 \pm 8.7$ & $50.3 \pm 3.1$ & $37.6 \pm 2.5$ & $34.6 \pm 2.8$ & $39.4 \pm 2.4$ \\
\hline Ramírez & 50 & $89.0 \pm 4.3$ & $130.7 \pm 8.1$ & $49.1 \pm 3.5$ & $37.1 \pm 1.9$ & $35.5 \pm 1.9$ & $40.2 \pm 2.1$ \\
\hline Maitas & 57 & $88.5 \pm 6.4$ & $130.3 \pm 6.5$ & $46.1 \pm 4.6$ & $36.2 \pm 2.2$ & $34.7 \pm 2.6$ & $39.6 \pm 1.9$ \\
\hline San Miguel & 20 & $87.1 \pm 4.2$ & $128.5 \pm 5.6$ & $47.9 \pm 3.5$ & $38.4 \pm 3.0$ & $35.4 \pm 2.0$ & $39.3 \pm 1.8$ \\
\hline Tiwanaku & 25 & $84.5 \pm 6.0$ & $128.2 \pm 6.3$ & $49.5 \pm 2.6$ & $37.0 \pm 1.8$ & $36.2 \pm 1.9$ & $40.4 \pm 2.8$ \\
\hline
\end{tabular}

Key to columns: $1=$ minimun frontal breadth; $2=$ bizygomatic breadth; $3=$ nasal heigth; $4=$ orbital breadth; $5=$ orbital heigth; $6=$ palatal breadth 
TABLE 3

Mahalanobis distances statistics among prehistoric populations belonging to various cultural phases present in the coastal valleys of Arica, Chile and one highland cranial sample.

Asterisks indicate statistically significant differences $(\mathrm{P}<0.05)$

Distancias de Mahalanobis entre poblaciones pertenecientes a varias fases culturales presentes en los valles costeros de Arica, Chile y una muestra altiplánica. Los asteriscos indican diferencias estadísticamente significativas $(\mathrm{P}<$ $0,05)$

\begin{tabular}{|c|c|c|c|c|c|c|}
\hline & Chinchorro & Azapa & Alto Ramírez & Maítas & San Miguel & Tiwanaku \\
\hline Chinchorro & - & & & & & \\
\hline Azapa & $2.05 *$ & - & & & & \\
\hline Alto Ramírez & $2.37 *$ & 0.88 & - & & & \\
\hline Maítas & $2.55^{*}$ & $1.44^{*}$ & $1.01 *$ & - & & \\
\hline San Miguel & $2.21 *$ & $1.35^{*}$ & 1.11 & 1.55 & - & \\
\hline Tiwanaku & $3.12 *$ & $1.67 *$ & 1.23 & $1.80 *$ & $1.25 *$ & - \\
\hline
\end{tabular}

after 2,500 years BP. The statistical significance of the association between MDS distances and time was tested using the Mantel test (Mantel 1967). We obtained $\mathrm{r}=0.82 ; \mathrm{P}=0.0451$ (9999 permutations) (Fig. 2). Neighbor-Joining (NJ) (Saitou \& Nei 1987) dendrogram was generated on the basis of the craniometric distance matrix (Fig. 3). The type of data used (craniometric variables) precluded the computation of bootstrap values to test the robustness of the dendrogram.

\section{DISCUSSION}

It was not the purpose of this study to investigate changes of the face resulting from intentional deformation, but to asses the impact of deformation on the measurements employed in our distance analysis, and to avoid a possible bias in our results caused by this practice. As described previously, intentional cranial deformation was not significantly associated with changes in six craniometric variables used in this study. As indicated by Anton (1989) both deformation types (AP and C) grade into the normal type $(\mathrm{N})$. Consequently, MDS between AP and $\mathrm{N}(0.13)$ and $\mathrm{C}$ and $\mathrm{N}(0.23)$, although statistically insignificant, were found to be smaller than the distance between AP and C (0.31).

From the archeological point of view the Andean highlands cultural influence begins in the coastal valleys of Arica around 2,500 years BP and is still strong during the Maitas phase (ca. AD 750-1,000). The San Miguel and Gentilar phases that followed (ca. AD 1,000-1,300) are characterized by some regional cultural elaborations. It should be remembered that these different phases are primarily defined on the basis

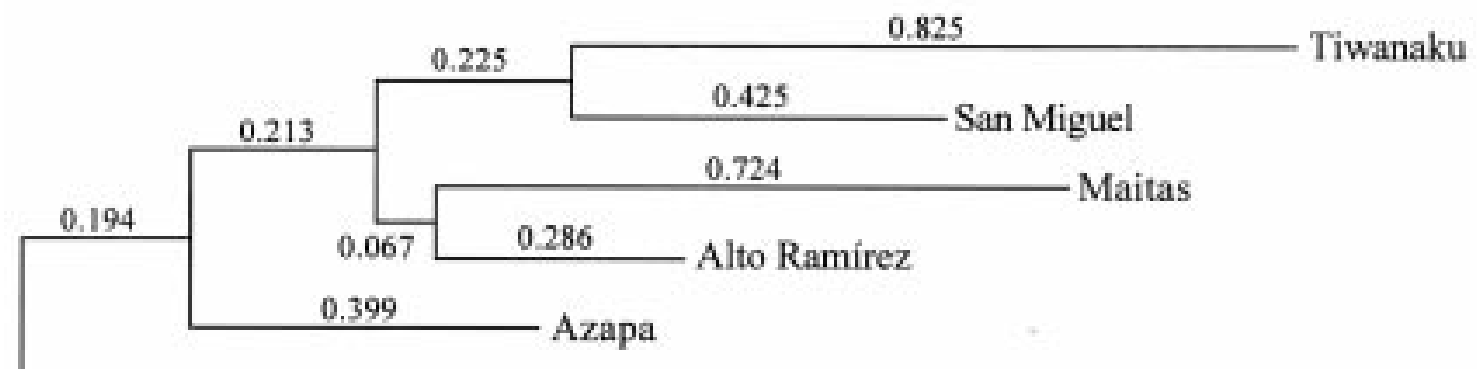

1.457

Chinchorro

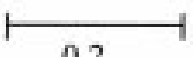

0.2

Fig. 3: Neighbor-Joining (NJ) dendrogram representing graphically the craniometrical variability observed among cultural phases.

Dendrograma confeccionado con el método Neighbor-Joining (NJ) que representa gráficamente la variabilidad observada entre fases culturales. 
of pottery, basketry and tapestry types, and represent probably the influence of different stages of cultural development in the Andean highlands, including after 1,600 years BP the Tiwanaku culture and, subsequently, the adaptation of these to local conditions.

Turning now to the craniometric data, we note that the Chinchorro phase exhibits relatively larger distances to all other phases particularly to Tiwanaku because of its chronological position. MDS tend to be smaller between chronologically adjacent phases, suggesting that the Chinchorro archaic coastal populations gave rise to bands of incipient agriculturalist who started to cultivate some crops in the lower Azapa valley. On the other hand, distances to the highland Tiwanaku sample, become statistically unsignificant during the Alto Ramírez phase, a time point when according to archeological data Andean highland cultural influence starts in the valley. This result agrees with the hypothesis that population displacements from the highlands may have been responsible for cultural development in the valley during and after the Alto Ramírez phase. The relatively low craniometrical distance between Tiwanaku and the late San Miguel phase probably indicates that migration from the highlands continued intermittently until the arrival of the conquerors in the XVI century.

We found a strong significant correlation between craniometrical and chronological distances in our samples. Since craniofacial differentiation is a function of time in the Azapa valley, it is possible to compute craniometrical microevolutionary rates taking the ratio between MDS and time. These rates would indicate genetic change, if we assume that environmental conditions in the valley were relatively stable during the period studied, thus not affecting heritability values. The rates obtained for Chinchorro and Azapa, which can be probably explained by drift, increase somewhat after Azapa and Alto Ramírez and are markedly higher after Maitas, indicating that although some gene flow from a genetically different population took place during the Alto Ramírez phase, a marked increase occured during the San Miguel phase. There are two additional explanations besides gene flow for the increase of microevolutionary rates, namely a demographic bottleneck or a drastic increase of mutation rates. There is no paleodemographic evidence for a bottleneck (which could have increased genetic drift) and a drastic increase of mutation rates seems very unlikely.

It is notewortly that the pattern of gene flow previously described is in agreement with the craniometrical distances analysis. The smallest distances were found between Tiwanaku and Alto Ramírez and Tiwanaku and San Miguel as mentioned earlier. Furthermore preliminary results of studies of ancient mtDNA that are under way in our laboratory corroborate craniometrical findings.

The dendrogram shown in Fig. 3 represents graphically the craniometrical variability encountered and is fully consistent with our conclusions. Chinchorro, the chronologically most distant sample located at the coast constitutes a separate cluster, whereas the samples from the Azapa valley are ordered hierarchically according to the chronology of the cultural phases to which they belong. It is noteworthy that Tiwanaku clusters together with San Miguel.

\section{LITERATURE CITED}

ALDENDERFER MS (1989) The archaic period in the South Central Andes. Journal of World Prehistory 3: 117-158.

ALLISON M G FOCACCI, B ARRIAZA, V STANDEN, M RIVERA \& J LOWENSTEIN (1984) Chinchorro, momias de preparación complicada: métodos de momificación. Chungara 13: 155-174.

ANTON S (1989) Intentional cranial vault deformation and induced changes of the cranial base and face. American Journal of Physical Anthropology 79: 253-267.

BASS WM (1971) Human osteology: a laboratory and field manual of the human skeleton. University of Missouri Press, Springfield, Missouri. 271 pp.

BAIED CA (1991) Late Quaternary environments and human occupation in the south central Andes. Ph.D. Dissertation, Department of Anthropology, University of Colorado, Boulder, Colorado. 376 pp.

DAUELSBERG P (1983) Tojotojone: un paradero de cazadores arcaicos. Características y secuencias. Chungará 11: 11-31.

FOCACCI G (1974) Excavaciones en el cementerio de Playa Miller 7, Arica. Chungara 3: 23-74.

FOCACCI G \& S ERICES (1973) Excavaciones en túmulos de San Miguel de Azapa. Actas del IV Congreso de Arqueología Chilena. Número Especial, pp. 44-55 Universidad de Chile, Santiago.

GROSJEAN M \& L NÚÑEZ (1994) Late glacial, early and middle holocene enviroments. Human occupations and resources use in the Atacama desert (northern Chile). Geoarchaeology 9: 271-286.

MAHALANOBIS P \& P MAJUMDAR (1949) Anthropometric survey of the United Provinces 1941: a statistical study. Sankhya 9: 89-324.

MANTEL N (1967) The detection of disease clustering and a generalized regression approach. Cancer Research 27: 209-220.

MORAGA M, E ASPILLAGA, C SANTORO, V STANDEN, P CARVALLO \& F ROTHHAMMER (2001) Análisis de ADN mitocondrial en momias del norte de Chile avala hipótesis de origen amazónico de poblaciones andinas. Revista Chilena de Historia Natural 74: 719-726. 
MUÑOZ Y \& G FOCACCI (1983) Asentamientos aldeanos en los valles costeros de Arica. Documento de trabajo No. 3, Universidad de Tarapacá, Arica, Chile. 43 pp.

POSNANSKY A (1914) Una metrópoli prehistórica en la América del Sur. Ernst Vohsen, Berlin, Germany. 275 pp.

RIVERA M \& F ROTHHAMMER (1986) Evaluación biológica y cultural de poblaciones Chinchorro: Nuevos elementos para la hipótesis de contactos transaltiplánicos cuenca Amazonas Costa Pacífico. Chungará 16-17: 295-307.

ROTHHAMMER F (1990) The Aymará: an outline of their pre and post-Columbian history. In: Schull WJ \& F Rothhammer (eds) The Aymará: strategies of human adaptation to a rigorous environment: 45-48. Kluwer Academic Publishers, Dordrecht, The Netherlands.

ROTHHAMMER F \& C SANTORO (2001) El desarrollo cultural en el Valle de Azapa, extremo norte de Chile y su vinculación con los desplazamientos poblacionales altiplánicos. Latin American Antiquity 12: 59-66.

ROTHHAMMER F \& C SILVA (1988) The peopling of Andean South America. American Journal of Physical Anthropology 77: 465-473.

ROTHHAMMER F \& C SILVA (1990) Craniometrical variation among South American prehistoric: climatic, altitudinal, chronological and geographic contributions. American Journal of Physical Anthropology 82: 9-17.
ROTHHAMMER F \& C SILVA (1992) Gene geography of South America: testing models of population displacement based on archaeological evidence. American Journal of Physical Anthropology 89: 441-446.

ROTHHAMMER F, E LLOP, P CARVALLO \& M MORAGA (2001) Origin and evolutionary relationships of native Andean populations. High Altitude Medicine \& Biology 2: 227-233.

SANTORO C (1980) Fase Azapa transición del arcaico al desarrollo agrario inicial en los valles bajos de Arica. Chungara 6: 45-56.

SANTORO C (1989) Antiguos cazadores de la puna (9.000 a 6.000 A.C). In: Hidalgo I, V Schiapacasse, H Niemeyer, C Aldunate \& I Solimano (eds) Culturas de Chile desde sus orígenes hasto los albores de la conquista: 33-55. Editorial Andres Bello, Santiago, Chile.

SANTORO C \& L NÚÑEZ (1987) Hunters of the dry puna and salt puna in northern Chile. Andean Past 1: 57110.

SAITOU N \& M NEI (1987) The neighbor-joining method: a new method for reconstructing phylogenetic trees. Molecular Biology and Evolution 4: 406-425.

SUTTER R (1997) Dental variation and biocultural affinities among prehistoric populations from the Coastal Valleys of Moquegua, Perú and Azapa Chile. Ph.D. Dissertation, University of Missouri, Columbia, Missouri. $428 \mathrm{pp}$. 